\title{
Detection of human cytomegalovirus in patients with epithelial ovarian cancer and its impacts on survival
}

\author{
Min Yin ${ }^{1 *}$, Aiping Chen ${ }^{2 *}$, Fei Zhao ${ }^{1}$, Xuechao $\mathrm{Ji}^{1}$, Chuan $\mathrm{Li}^{1}$ and Guangning Wang ${ }^{1}$
}

\begin{abstract}
Background: The cause of epithelial ovarian cancer (EOC) is not elucidated. Viral infection may induce chronic inflammatory infection and play a role in the pathogenesis of cancers. Some viruses are considered to be oncomodulatory, modulating cellular pathways such as cell proliferation, tumor progression, vascular disease development, and immune evasion. Human cytomegalovirus (HCMV) has been detected in several types of cancers including ovarian cancer. However, the role of HCMV in ovarian carcinogenesis remains controversial.

Objective: To investigate the potential role of HCMV infection in EOC, we evaluated the prevalence of HCMV proteins in EOC tissue and its impacts on patients' survival.

Methods: Formalin-fixed paraffin-embedded tissues from 66 patients with EOC and 30 patients with benign ovarian cystadenoma were studied. Specimens were analyzed for expression of HCMV immediate early protein (IE) and HCMV tegument protein (pp65) by immunohistochemistry.

Results: HCMV-IE protein expression was detected in $82 \%$ of EOC and 36\% of benign tumors; pp65 was detected in $97 \%$ of EOC and $63 \%$ of benign tumors. Extensive HCMV-IE protein expression was associated with higher stage of EOC. Reactivation of latent HCMV within the tumor at interval debulking surgery may be induced by neoadjuvant chemotherapy before surgery. Extensive HCMV-IE expression was associated with shorter median overall survival than focal or negative expression (39 versus 41 months, $P=0.03$ ). Multivariate analysis indicated that HCMV-IE expression was an independent prognostic factor for overall survival $(P=0.034)$.

Conclusions: This study demonstrate a high prevalence of HCMV proteins in tissue sections from patients with EOC. HCMV infection can be potential risk factor for EOC development. Extensive HCMV-IE expression indicated a poor prognosis. The relationship between HCMV and clinical outcomes highlight the need for further researches on the oncomodulatory role of HCMV in ovarian cancer.
\end{abstract}

Keywords: Epithelial ovarian cancer, Human cytomegalovirus, Viral carcinogenesis, Survival

\section{Introduction}

Ovarian cancer is a major cause of cancer deaths in women. Patients are often diagnosed with advancedstage due to the lack of effective screening methods and

\footnotetext{
*Correspondence: 1239096840@qq.com; chenaiping516@163.com ${ }^{1}$ Medical College of Qingdao University, Qingdao, Shandong Province, China 2Department of Gynecology, The Affiliated Hospital of Qingdao University, Qingdao, Shandong Province, China
}

the non-specific symptoms. Ovarian cancer is a highly fatal disease, with a global 5-year survival rate of 30 $40 \%$ in women at advanced stages of diagnosis [1]. However, our understanding of the exact cause of ovarian cancer is limited. During recent years, serous tubal intraepithelial carcinomas (STIC) have been shown to be precursor lesions of serous EOC [2]. Anatomically, the female peritoneal cavity and internal genitalia are

(c) The Author(s). 2020 Open Access This article is licensed under a Creative Commons Attribution 4.0 International License, which permits use, sharing, adaptation, distribution and reproduction in any medium or format, as long as you give appropriate credit to the original author(s) and the source, provide a link to the Creative Commons licence, and indicate if changes were made. The images or other third party material in this article are included in the article's Creative Commons licence, unless indicated otherwise in a credit line to the material. If material is not included in the article's Creative Commons licence and your intended use is not permitted by statutory regulation or exceeds the permitted use, you will need to obtain permission directly from the copyright holder. To view a copy of this licence, visit http://creativecommons.org/licenses/by/4.0/ The Creative Commons Public Domain Dedication waiver (http://creativecommons.org/publicdomain/zero/1.0/) applies to the data made available in this article, unless otherwise stated in a credit line to the data. 
accessible to outside pathogens through the genital tract. Furthermore, the fallopian tubes are easily affected by pelvic inflammatory disease (PID), it is therefore highly hypothesized that microbial infection may contribute to ovarian cancer [3].

HCMV is a member of the $\beta$-herpesviruses family, which can establish life-long latency. If the patient's immunological status is impaired, the viral replication cycle will be reactivated [4]. During active infection, HCMV expresses several proteins, some are essential for its replication and a large amount may interfere with the cellular and immunological functions, enabling the virus to coexist with its host [5]. Recently, several studies provide evidence that HCMV proteins and nucleic acid has been detected in tissue from several malignancies, including cervical, breast, colorectal, as well as glioblastoma and neuroblastoma [6-10]. Shanmughapriya et al. first found HCMV-glycoprotein DNA by polymerase chain reaction analysis in $50 \%$ of tumor tissue specimens from ovarian cancer patients [11]. Carlson et al. reported that HCMV proteins and nucleic acids are frequently detected at different levels in high grade serous ovarian carcinoma, and shorter median overall survival was shown in patients with positive HCMV IE and pp65 [12]. Lately, Paradowska et al. analyzed the prevalence of human papillomavirus (HPV) and HCMV in EOC tissue and fallopian tube specimens obtained at tumor resection [13]. The presence of HCMV and HPV DNA was detected in 70 and $74 \%$ cancerous ovarian tissues, respectively, and was significantly higher in EOC than in benign tumor cases. HCMV or HPV infection was observed also in the fallopian tube samples. Two thirds of EOC patients demonstrated coinfection with HCMV and HPV in the pathological samples, suggesting that the infections of HCMV and HPV can be potential risks for EOC development. However, Ingerslev et al. examined the prevalence of Epstein-Barr Virus (EBV) DNA and HCMV DNA in EOC tissue samples, HCMV DNA was detected in only one case sample (0.5\%), showing no association between HCMV and EOC [14].

To elucidate the potential role of HCMV in ovarian cancer and possible impact of HCMV infection on the clinical outcomes, we investigated the prevalence of HCMV proteins in EOC tissue and compared findings to those obtained in benign ovarian cystadenoma.

\section{Materials and methods}

\section{Clinical samples}

Between January and December 2015, 66 patients with EOC and 30 patients with benign ovarian cystadenoma were enrolled in the study. All patients underwent surgery and received treatments at the Gynecology
Department in The Affiliated Hospital of Qingdao University. Thirty-four patients had primary debulking surgery, and 32 had interval debulking surgery after NACT. All patients received conventional adjuvant chemotherapy after the surgery. Carboplatin AUC5 and paclitaxel $175 \mathrm{mg} / \mathrm{m}^{2}$ intravenously every third week in total 6 to 8 cycles is recommended according to the guidelines. The clinical follow-up continued to December 2019. Either re-examination in the outpatient or phone interview was used to determine the patients' condition during the follow-up. Overall survival (OS) was defined as the time interval from the date of diagnosis with clinical pathology to the date of EOC-related death or the last follow-up. The study was approved by the medical ethics committee of The Affiliated Hospital of Qingdao University. Since all specimens were collected anonymously, the Medical Ethics Committee exempted patients from the need for informed consent.

\section{Immunohistochemical analyses of paraffin sections}

Formalin-fixed paraffin-embedded surgical specimens were obtained from the pathology tissue archives of the hospital. Four micrometer paraffin sections were deparaffinized in the xylene, and hydrated them in graded alcohols. For antigen retrieval, tissue sections were performed by treatment with pepsin (BioSite) at $37^{\circ} \mathrm{C}$ for $15 \mathrm{~min}$, at $\mathrm{pH} 7.6$ and overnight incubation at $37^{\circ} \mathrm{C}$. Endogenous nonspecific binding of antibodies was blocked with $3 \% \quad \mathrm{H}_{2} \mathrm{O}_{2}$ (Bioss, China), avidin/biotin blocking reagents (Bioss, China), FC receptor blocker (Bioss, China). Monoclonal antibodies against HCMV IE protein (Millipore, USA) and HCMV tegument protein pp65 (Bioss, China) were used for the detection of different HCMV proteins. The extent of HCMV infection was scored as follows: negative ( $0 \%$ positive cells), focal $(<$ $50 \%$ positive cells), or extensive ( $\geq 50 \%$ positive cells), estimating from the number of cells expressing HCMV proteins, according to the score criteria from Radestad et al. [15]. All staining results were independently reviewed by two pathologists.

\section{Statistical analyses}

Immunohistochemical data were determined in EOC and benign ovarian cystadenoma samples. All statistical analyses were performed using SPSS version 19.0 (SPSS Inc., Chicago, IL, USA). Chi-square tests were applied to analyse categorical data. OS was presented as KaplanMeier survival curves. The statistical significance of survival data was determined by log-rank test. Multivariate Cox proportional hazards regression model was used to assess the independent predictive factors. $P<0.05$ was considered significant. 
Table 1 Patients characteristics

\begin{tabular}{|c|c|}
\hline \multicolumn{2}{|l|}{ Patients characteristics } \\
\hline Epithelial ovarian cancer $(n=66)$ & $n(\%)$ \\
\hline \multicolumn{2}{|l|}{ Age } \\
\hline$<50 y$ & 8 \\
\hline $50-60 y$ & 24 \\
\hline $60-70 y$ & 32 \\
\hline$\geq 70 y$ & 2 \\
\hline \multicolumn{2}{|l|}{ Initial CA125 } \\
\hline$<35 \mathrm{U} / \mathrm{ml}$ & 4 \\
\hline$\geq 35 \mathrm{U} / \mathrm{ml}$ & 62 \\
\hline \multicolumn{2}{|l|}{ Pathological type } \\
\hline Serous adenocarcinoma & 54 \\
\hline Mucinous adenocarcinoma & 2 \\
\hline Endometrioid adenocarcinoma & 2 \\
\hline Clear cell carcinoma & 8 \\
\hline \multicolumn{2}{|l|}{ Stage } \\
\hline 1,1 & 8 \\
\hline$\| I I, I V$ & 58 \\
\hline Neoadjuvant chemotherapy before surgery & 32 \\
\hline \multicolumn{2}{|l|}{ Benign ovarian cystadenoma $(n=30)$} \\
\hline \multicolumn{2}{|l|}{ Age } \\
\hline $10-30 y$ & 5 \\
\hline $30-50 y$ & 6 \\
\hline$>50 y$ & 19 \\
\hline \multicolumn{2}{|l|}{ Initial CA125 } \\
\hline$<35 \mathrm{U} / \mathrm{ml}$ & 26 \\
\hline$\geq 35 \mathrm{U} / \mathrm{ml}$ & 4 \\
\hline \multicolumn{2}{|l|}{ Pathological type } \\
\hline Serous cystadenoma & 13 \\
\hline Mucinous cycstadenoma & 17 \\
\hline
\end{tabular}

\section{Results}

\section{Patients characteristics}

The mean age of the 66 patients with EOC was 57 years old, ranged from 45 to 71 years. At study closure, 25 out of $66(38 \%)$ patients were alive. Thirty patients with benign ovarian cystadenoma served as controls. The mean age of the controls was 43 years old, ranged from 16 to 62 years. The detailed information was shown in Table 1.
Immunohistochemistry for HCMV

HCMV-IE protein was detected from $82 \%$ of EOC patients and $36 \%$ of patients with benign cystadenoma (Table 2). HCMV-IE protein expression was extensive in $61 \%$, focal in $21 \%$ and negative in $18 \%$ of EOC tissues. Moreover, expression was extensive in $23 \%$, focal in $13 \%$ and negative in $64 \%$ of benign ovarian cystadenoma (Fig. 1). HCMV-pp65 protein was detected in tumor specimens from $97 \%$ of EOC patients and $63 \%$ of those with benign cystadenoma (Table 2). The expression was extensive in $76 \%$, focal in $21 \%$ and negative in $3 \%$ in epithelial ovarian cancer tissue. Furthermore, expression was extensive in $33 \%$, focal in $30 \%$ and negative in $37 \%$ in benign ovarian cystadenoma (Fig. 2).

\section{Association between high HCMV expression proteins and advanced disease}

Next we analyzed the effects of HCMV on the EOC stage. HCMV-IE expression was extensive in $25 \%$ of Stage I-II tumors, $66 \%$ of Stage III-IV tumors; HCMVpp65 expression was extensive in 38 and $64 \%$ of stage III and stage III-IV tumors, respectively. We observed that advanced tumor stage was correlated with extensive expression of HCMV-IE $(P=0.0279)$ (Table 3$)$.

\section{Reactivation of latent HCMV and NACT}

HCMV-IE expression was extensive in $75 \%$ of cancer tissue with NACT before surgery, $47 \%$ of cancer tissue without NACT; HCMV-pp65 expression was extensive in 69 , and $53 \%$, respectively. This observation indicates that reactivation of latent $\mathrm{HCMV}$ within the tumor at interval debulking surgery (IDS) may be induced with NACT as HCMV-IE viral proteins could be significantly extensive expressed in tumor tissue sections with NACT before $\operatorname{surgery}(P=0.0279)$ (Table 4$)$.

\section{Survival rate among EOC patients with extensive HCMV-IE expression}

To confirm the effects of HCMV on EOC clinical outcomes, we analyzed the overall survival by the KaplanMeier survival analysis. At study closure, $77 \%$ of patients with focal or negative expression of HCMV-IE in their tumors were alive versus $32 \%$ of those with extensive expression. The results showed that EOC patients who had focal or negative HCMV-IE expression in their tumors had significantly longer median OS than those with extensive HCMV-IE expression (41 vs.39 months, $P=0.03$ )

Table 2 Expression of HCMV-IE and pp65 in EOC and Benign Ovarian Cystadenoma

\begin{tabular}{|c|c|c|c|c|c|c|}
\hline \multirow[t]{2}{*}{ Type of tumor } & \multicolumn{3}{|l|}{ HCMV IE } & \multicolumn{3}{|l|}{ HCMV PP65 } \\
\hline & Extensive, n(\%) & Focal, n(\%) & Negative, n(\%) & Extensive, n(\%) & Focal, n(\%) & Negative, n(\%) \\
\hline EOC & $40 / 66(61)$ & $14 / 66(21)$ & 12/66(18) & $50 / 66(76)$ & $14 / 66(21)$ & $2 / 66(3)$ \\
\hline Ovarian cystadenoma & $7 / 30(23)$ & 4/30(13) & 19/30(64) & 10/30(33) & $9 / 30(30)$ & $11 / 30(37)$ \\
\hline
\end{tabular}




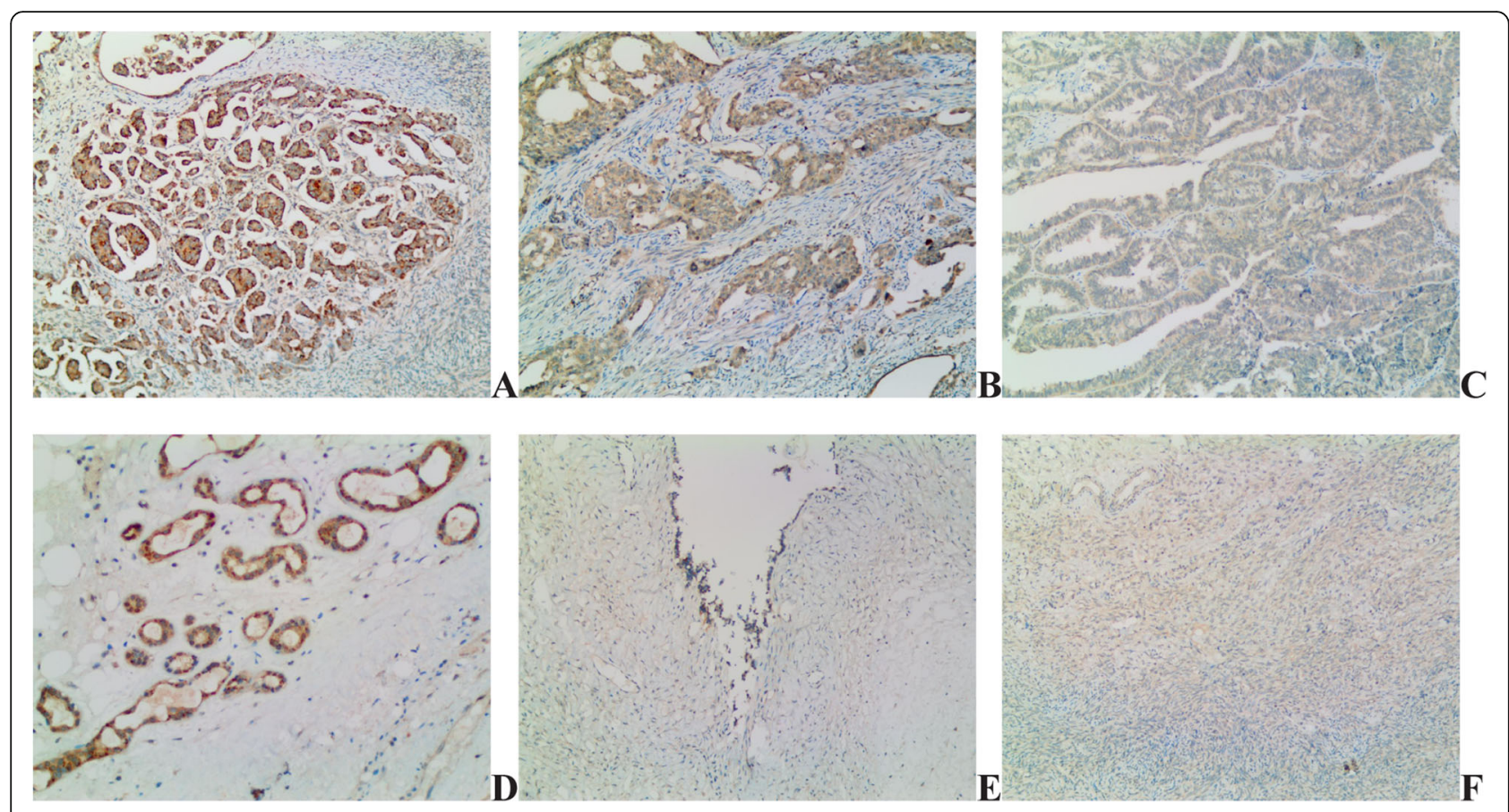

Fig. 1 Detection of HCMV-IE in EOC tissue and benign ovarian cytstadenoma. HCMV IE extensive (a), focal (b) and negative (c) expression in EOC. HCMV IE extensive $(\mathbf{d})$, focal $(\mathbf{e})$ and negative $(\mathbf{f})$ expression in benign ovarian cystadenoma sections $(10 \times 10)$
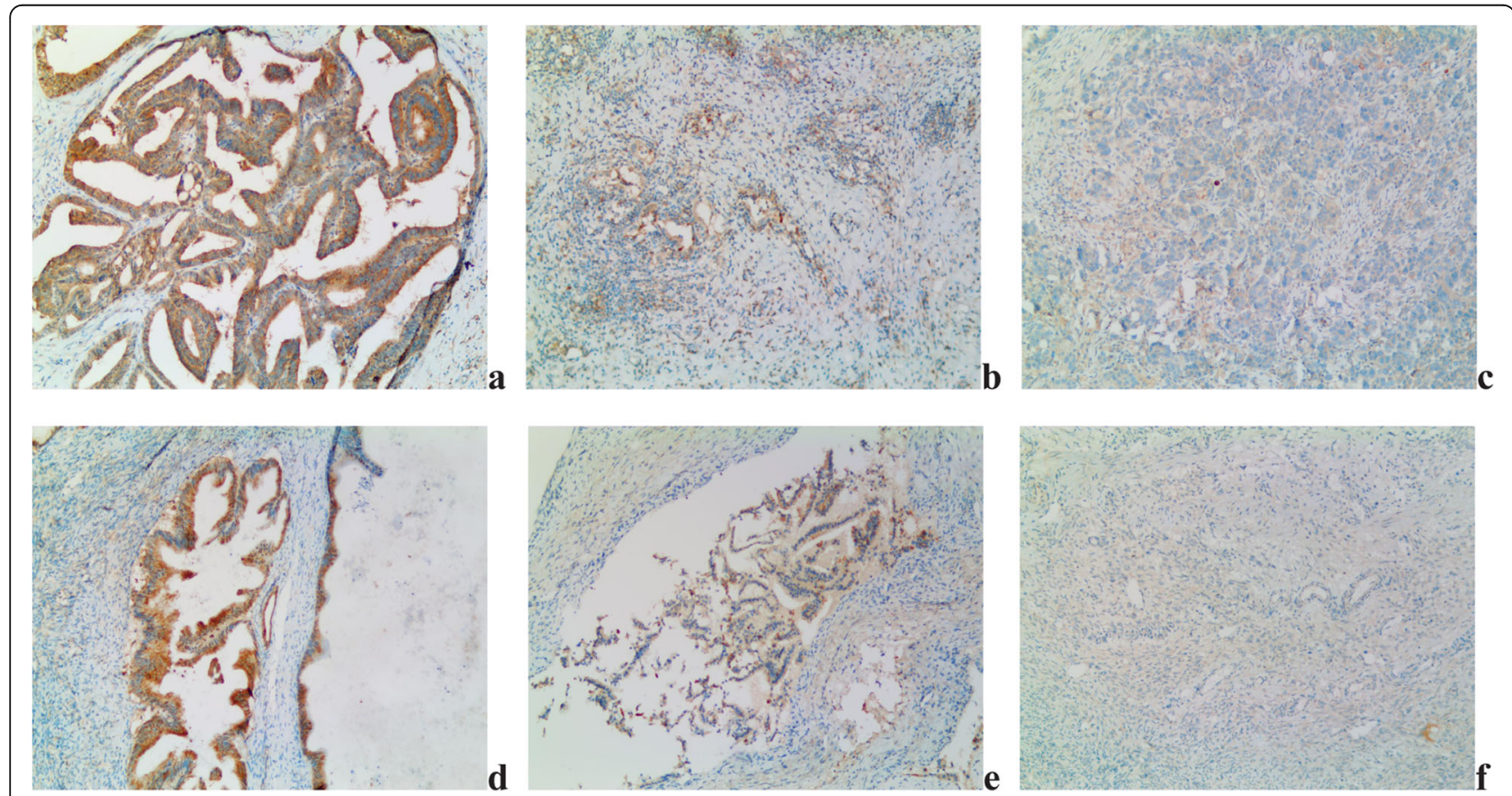

Fig. 2 Detection of HCMV-pp65 in EOC tissue sections and benign ovarian cytstadenoma. HCMV pp65 extensive (a), focal (b) and negative (c) expression in EOC. HCMV pp65 extensive (d), focal (e) and negative (f) expression in benign ovarian cystadenoma sections $(10 \times 10)$ 
(Fig. 3a). Similarly, $26 \%$ of patients with focal or negative HCMV-pp65 protein expression were alive versus $61 \%$ with extensive expression; however, no significant difference in OS was observed(42 vs. 40 months, $P=0.37$ ) (Fig. 3b).

To determine whether HCMV-IE expression was an independent risk factor for the OS of EOC patients, we conducted both univariate and multivariate analyses. FIGO stage $(P=0.024)$ and HCMV-IE expression $(P=$ 0.032 ) were prognostic factors for OS in patients with EOC, shown from univariate analysis. Furthermore, the multivariate analysis indicated that HCMV-IE expression $(P=0.034)$ were independent prognostic factors for OS (Table 5).

\section{Discussion}

In our study, we studied HCMV-IE and pp65 proteins. We found that the presence of HCMV-IE and pp65 was detected both in EOC and benign ovarian cystadenoma. However, the positive rates of both proteins in EOC were higher than that in ovarian cystadenoma. This may be due to the fact that the average age of patients with ovarian cystadenoma is lower than that of EOC, while age is one of the risk factors of HCMV infection. Cannon et al. reviewed the literature in order to learn about HCMV transmission and risk factors of infection. They found that HCMV seroprevalence generally increased with age in all 32 studies. In most of the studies that stratified by age, HCMV infection prevalence reached $60 \%$ or more in people older than 50 [16]. Moreover, we found that extensive expression of HCMV-IE was correlated with advanced tumor stage. The rate of extensive expression of HCMV-IE in cancer tissue with NACT before surgery was higher than those without NACT. The median OS was shorter among ovarian cancer patients who had extensive expression of HCMV-IE in their tumors than in those with focal or negative expression. And extensive HCMV-IE expression was an independent prognostic factor of OS. These findings suggest that HCMV may have an oncomodulatory effect that contributes to disease progression of EOC patients. To our knowledge, this is the first demonstration of HCMV

Table 3 Expression of HCMV-IE and pp65 in EOC tissues of different stages

\begin{tabular}{|c|c|c|c|c|}
\hline & Extensive, n(\%) & Focal/negative, n(\%) & Chi-square & $P$ \\
\hline HCMV-IE & & & 4.834 & 0.0279 \\
\hline I,II & $2(25)$ & $6(75)$ & & \\
\hline III,IV & $38(66)$ & 20(34) & & \\
\hline HCMV-pp65 & & & 2.036 & 0.1536 \\
\hline$||$, & $3(38)$ & $5(62)$ & & \\
\hline III,IV & $37(64)$ & $21(36)$ & & \\
\hline
\end{tabular}

infection in patients with EOC among Chinese population.

HCMV is a widespread opportunistic pathogen which is estimated to be carried by $40-100 \%$ of the world's population. The infection rate varies according to geographical location, socioeconomic status and age [17]. HCMV can survive in latent form in an immunocompetent host, while it is reactivated during immunosuppression. Several studies have identified high frequency of active HCMV infection in tumor tissues [6-10]. HCMV is considered to be oncomodulatory, although the mechanisms are not clearly understood [18]. The concept of "oncomodulation" suggests that a virus may modulate cellular pathways such as cell proliferation, tumor progression, vascular disease development, and immune evasion [19]. Therefore, HCMV infection may promote malignant transformation by dysregulating the cell cycle and controlling some key physiological processes. Till now, there have been a number of studies suggesting that HCMV proteins such as IE, pp65 and other encoded proteins enable the virus to play an oncomodulatory role [20]. For example, HCMV encodes proteins IE1, IE2, pp71, and pUL97 that can bind or phosphorylate $\mathrm{Rb}$ family proteins and inhibit the cell cycle arrest functions of p53. Moreover, HCMV induces a mesenchymal-to-epithelial transition [21]. HCMV-IE often serves as transcription factors that regulate the expression of both viral and host cellular genes, which are crucial to efficient viral replication. IE can also activate production of early and late structural viral proteins, including the viral tegument protein pp65 [22]. HCMVpp65 is an immunomodulatory protein. It affects expression of HLA-class II and thereby helps the virus to avoid recognition and killing of infected cells by $\mathrm{T}$ cells [23]. Thus, HCMV-pp65 expression might worsen patient outcome by mediating an immunosuppressive state in the tumor microenviroment.

In cancers which are not attributable to infectious agents, chronic inflammation may also play a critical role

Table 4 Expression of HCMV-IE and pp65 in EOC tissues with/ without NACT

\begin{tabular}{lllll}
\hline & $\begin{array}{l}\text { Extensive, } \\
\mathrm{n}(\%)\end{array}$ & $\begin{array}{l}\text { Focal/negative, } \\
\mathrm{n}(\%)\end{array}$ & $\begin{array}{l}\text { Chi- } \\
\text { square }\end{array}$ & $\mathrm{P}$ \\
\hline HCMV-IE & & & 5.390 & 0.0202 \\
$\begin{array}{l}\text { NACT before } \\
\text { surgery }\end{array}$ & $24(75)$ & $8(25)$ & & \\
$\begin{array}{l}\text { No NACT before } \\
\text { surgery }\end{array}$ & $16(47)$ & $18(53)$ & & \\
$\begin{array}{l}\text { HCMV-pp65 } \\
\text { NACT before } \\
\text { surgery }\end{array}$ & 22(69) & $10(31)$ & & \\
$\begin{array}{l}\text { No NACT before } \\
\text { surgery }\end{array}$ & $18(53)$ & $16(47)$ & & \\
\hline
\end{tabular}



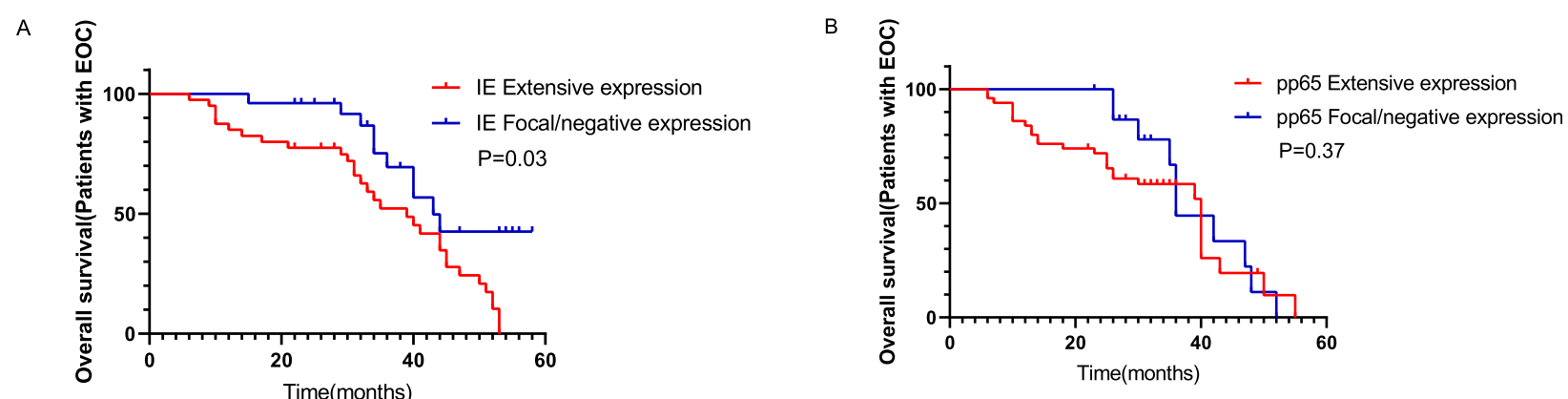

Fig. 3 Survival curves of EOC patients with HCMV protein expression. a EOC patients who had focal or negative HCMV-IE expression in their tumors had significantly longer median OS than those with extensive HCMV-IE expression (41 vs.39 months, $P=0.03$ ). b No significant difference in OS was observed in EOC patients with focal/negative or extensive HCMV-pp65 expression in their tumors (42 vs. 40 months, $P=0.37$ )

in the transition from a precancerous condition to invasive malignancy [24]. Ovarian cancer is a highly fatal disease and high grade serous ovarian carcinoma (HGSOC) is the most aggressive and common subtype of EOC. Recently the fimbriae of the fallopian tube have been suggested as the precancerous site of HGSOC [25]. Pelvic inflammatory disease (PID), an infection of the female reproductive organs, also results in the possibility of ovarian oncogenesis. Previous studies have implied a potential role of inflammatory factors in the ovarian malignancy process [3]. Inflammation is a key factor of the reactivation of latent HCMV. Active HCMV infection may aggravate the inflammatory microenvironment by increasing production of inflammatory factors such as viral IL-10, tumor necrosis factor- $\alpha$, transforming growth factor- $\beta$ and prostaglandins [26]. Baryawno et al. showed a suppressive role of the cyclooxygenase- 2 inhibitor in a xenograft model of medulloblastoma, indicating that anti-inflammatory drugs can reduce HCMV replication [27]. Paradowska et al. reported low amounts of viral DNA copies in EOC tissues, suggesting that HCMV exists in ovarian and fallopian tube cells in a latent phase and could be reactivated under the influence of the inflammatory tumor microenvironment [13]. Their study proved the role of HCMV as an oncomodulator rather than involving in direct transformation. Rahbar et al. recently found that prolactin (PRL) and prolactin (PRLR) receptor were induced to high levels in HCMV-infected ovarian cancer cells and PRLR expression was extensively detected in HCMV-infected ovarian tissue specimens [28]. Highly induced PRL and PRLR by HCMV infection may be of relevance for the oncomodulatory role of $\mathrm{HCMV}$ in ovarian cancer.

There are also a number of reports concerning HCMV reactivation in patients receiving chemotherapy. In our study, we found that the rate of extensive HCMV-IE protein expression in cancer tissue with NACT before surgery was higher than those without NACT. Chemotherapy might significantly suppress cellular immunity and expose patients to a greater risk of HCMV infection. It is possible that latent HCMV could subsequently be reactivated by the chemotherapy before or the dysregulated inflammatory tumor microenvironment [29].

In this study, multivariate analyses showed extensive HCMV-IE protein expression to be an independent risk factor for the OS of EOC patients. This is in line with Radestad et al. who found that extensive expression of HCMV-pp65 was significantly associated with OS, and median OS was 14 months longer in patients with latestage serous ovarian carcinoma who had focal expression of HCMV-pp65 in their tumor than in those with extensive expression [15].

Despite surgery and standard therapy, ovarian cancer patients have poor outcomes. Our findings suggest antiviral therapy may have place in future cancer treatment. Preliminary studies in anti-HCMV therapy adding on to standard therapy showed highly improved survival among glioblastoma patients [30]. Future studies are

Table 5 Univariate and multivariate analyses of variables for overall survival

\begin{tabular}{lllll}
\hline Variable & \multicolumn{2}{l}{ Univariate analysis } & & \multicolumn{1}{l}{ Multivariate analysis } \\
\cline { 2 - 3 } & $\mathrm{HR}(95 \% \mathrm{Cl})$ & $\mathrm{HR}(95 \% \mathrm{Cl})$ & \\
\hline Age & $0.890(0.724-1.134)$ & 0.332 & \\
Initial CA125 & $1.124(0.767-1.564)$ & 0.643 & & \\
Pathological type & $0.893(0.546-1.422)$ & 0.436 & $1.154(1.005-1.457)$ & 0.167 \\
FIGO stage & $1.097(1.037-1.946)$ & 0.024 & $1.012(1.003-1.522)$ & 0.034 \\
HCMV-IE expression & $1.008(0.978-1.475)$ & 0.032 & \\
\hline
\end{tabular}


merited to evaluate antiviral treatment in patients with HCMV-positive tumors that have a poor prognosis. The main limitations of the present study were the small sample size and the limited availability of some clinical materials. Further studies with refined design are merited to validate these findings in a larger cohort of patients.

\section{Conclusion}

In the present study, HCMV-IE and pp65 were frequently detected in EOC tissue specimens, and extensive HCMV-IE protein expression was significantly associated with worse outcomes. Evidently HCMV affects the clinical outcomes of EOC, this virus may provide a new therapeutic target in EOC. Our observations suggest that EOC patients who had extensive HCMV-IE expression in their tumors had significantly poor survival rate. Therefore, antiviral therapy may have place in future cancer treatment.

\section{Abbreviations}

AUC: Area under curve; EOC: Epithelial ovarian cancer; EBV: Epstein-barr virus; FIGO: International Federation of Gynecology and Obstetrics; HCMV: Human cytomegalovirus; IDS: Interval debulking surgery; IL: Interleukin; NACT: Neoadjuvant Chemotherapy; OS: Overall survival; PID: Pelvic inflammatory disease; STIC: Serous tubal intraepithelial carcinomas

\section{Acknowledgments}

The authors would like to acknowledge the Gynecology teams in The Affiliated Hospital of Qingdao University. We also thank the pathology laboratory scientist Han Zhao for his valuable contributions to the experiment part

\section{Authors' contributions}

MY and APC designed the study. FZ and XCJ performed data collection. MY, FZ and CL performed pathological analyses. CL, MY and GNW analyzed the data and performed statistical analyses. All authors contributed to the writing of the proposal and manuscript. The authors read and approved the final version of the manuscript.

\section{Funding}

This work was supported by grant number 2017 M21 "Clinical medicine+X" from Qingdao University, China.

\section{Availability of data and materials}

The data used during the current study is available from the corresponding author on reasonable request.

\section{Ethics approval and consent to participate}

The protocol for the research project was approved by the Medical Ethics Committee of our hospital. Since all specimens used were anonymous, the Medical Ethics Committee exempted patients from the need for informed consent.

\section{Consent for publication}

Not applicable.

\section{Competing interests}

The authors declare that they have no competing interests.
Received: 29 January 2020 Accepted: 3 April 2020

Published online: 15 April 2020

\section{References}

1. Torre LA, Islami F, Siegel RL, Ward EM, Jemal A. Global cancer in women: burden and trends. Cancer Epidemiol Biomark Prev. 2017;26(4):444-57.

2. Kurman RJ, Vang R, Junge J, Hannibal CG, Kjaer SK, Shih IM. Papillary tubal hyperplasia: the putative precursor of ovarian atypical proliferative (borderline) serous tumors, noninvasive implants, and endosalpingiosis. Am J Surg Pathol. 2011;35(11):1605-14.

3. Ingerslev K, Hogdall E, Schnack TH, Skovrider-Ruminski W, Hogdall C, Blaakaer J. The potential role of infectious agents and pelvic inflammatory disease in ovarian carcinogenesis. Infect Agent Cancer. 2017;12:25.

4. Chou S. Advances in the genotypic diagnosis of cytomegalovirus antiviral drug resistance. Antivir Res. 2020;176:104711.

5. Dupont L, Reeves MB. Cytomegalovirus latency and reactivation: recent insights into an age old problem. Rev Med Virol. 2016;26(2):75-89.

6. Marinho-Dias J, Sousa H. Cytomegalovirus infection and cervical cancer: from past doubts to present questions. Acta Medica Port. 2013;26(2):154-60.

7. Richardson AK, Walker LC, Cox B, Rollag H, Robinson BA, Morrin H, et al. Breast cancer and cytomegalovirus. Clinical \& translational oncology: official publication of the Federation of Spanish Oncology Societies and of the National Cancer Institute of Mexico. 2020;22(4):585-602.

8. Bai $B$, Wang $X$, Chen $E$, Zhu H. Human cytomegalovirus infection and colorectal cancer risk: a meta-analysis. Oncotarget. 2016;7(47):76735-42.

9. Lisyany NI, Klyuchnikova AA, Belskaya LN, Lisyany AA, Gnedkova IA. Cytomegaloviruses and malignant brain tumors. Exp Oncol. 2019;41(4):300-3.

10. Maple PAC. Cytomegalovirus and Epstein-Barr Virus Associations with Neurological Diseases and the Need for Vaccine Development. Vaccines. 2020:8(1):35.

11. Shanmughapriya S, Senthilkumar G, Vinodhini K, Das BC, Vasanthi N Natarajaseenivasan K. Viral and bacterial aetiologies of epithelial ovarian cancer. Eur J Clin Microbiol Infect Dis. 2012;31(9):2311-7.

12. Carlson JW, Radestad AF, Soderberg-Naucler C, Rahbar A. Human cytomegalovirus in high grade serous ovarian cancer possible implications for patients survival. Medicine (Baltimore). 2018;97(4):e9685

13. Paradowska E, Jablonska A, Studzinska M, Wilczynski M, Wilczynski JR. Detection and genotyping of CMV and HPV in tumors and fallopian tubes from epithelial ovarian cancer patients. Sci Rep. 2019;9(1):19935.

14. Ingerslev K, Hogdall E, Skovrider-Ruminski W, Schnack TH, Lidang M, Hogdall C, et al. The prevalence of EBV and CMV DNA in epithelial ovarian cancer. Infect Agent Cancer. 2019;14:7.

15. Radestad AF, Estekizadeh A, Cui HL, Kostopoulou ON, Davoudi B, Hirschberg $\mathrm{AL}$, et al. Impact of human cytomegalovirus infection and its immune response on survival of patients with ovarian cancer. Transl Oncol. 2018; 11(6):1292-300.

16. Cannon MJ, Schmid DS, Hyde TB. Review of cytomegalovirus seroprevalence and demographic characteristics associated with infection. Rev Med Virol. 2010;20(4):202-13.

17. Chen SJ, Wang SC, Chen YC. Antiviral agents as therapeutic strategies against cytomegalovirus infections. Viruses. 2019;12(1):21.

18. Maleki F, Sadigh ZA, Sadeghi F, Muhammadnejad A, Farahmand M, Parvin $M$, et al. Human cytomegalovirus infection in Iranian glioma patients correlates with aging and tumor aggressiveness. J Med Virol. 2020.

19. LV YL, Han FF, Gong LL, Liu H, Ma J, Yu WY, et al. Human cytomegalovirus infection and vascular disease risk: a meta-analysis. Virus Res. 2017;227:12434.

20. Herbein G. The Human Cytomegalovirus, from Oncomodulation to Oncogenesis. Viruses. 2018:10(8):408.

21. Oberstein A, Shenk T. Cellular responses to human cytomegalovirus infection: induction of a mesenchymal-to-epithelial transition (MET) phenotype. Proc Natl Acad Sci U S A. 2017;114(39):E8244-E53.

22. Yang $Y$, Ren $G$, Wang Z, Wang B. Human cytomegalovirus IE2 protein regulates macrophage-mediated immune escape by upregulating GRB2 expression in UL122 genetically modified mice. Biosci Trends. 2020;13(6): 502-9.

23. Biolatti M, Dell'Oste V, De Andrea M, Landolfo S. The human cytomegalovirus tegument protein pp65 (pUL83): a key player in innate immune evasion. New Microbiol. 2018;41(2):87-94.

24. Pathak S, Wilczynski JR, Paradowska E. Factors in Oncogenesis: Viral Infections in Ovarian Cancer. Cancers. 2020;12(3):561. 
25. George SH, Garcia R, Slomovitz BM. Ovarian cancer: the fallopian tube as the site of origin and opportunities for prevention. Front Oncol. 2016;6:108.

26. Clendenen TV, Lundin E, Zeleniuch-Jacquotte A, Koenig KL, Berrino F, Lukanova $A$, et al. Circulating inflammation markers and risk of epithelial ovarian cancer. Cancer Epidemiol Biomark Prev. 2011;20(5):799-810.

27. Baryawno N, Rahbar A, Wolmer-Solberg N, Taher C, Odeberg J, Darabi A et al. Detection of human cytomegalovirus in medulloblastomas reveals a potential therapeutic target. J Clin Invest. 2011;121(10):4043-55.

28. Rahbar A, AlKharusi A, Costa H, Pantalone MR, Kostopoulou ON, Cui HL, et al. Human Cytomegalovirus Infection Induces High Expression of Prolactin and Prolactin Receptors in Ovarian Cancer. Biology. 2020;9(3):44.

29. Kuo CP, Wu CL, Ho HT, Chen CG, Liu SI, Lu YT. Detection of cytomegalovirus reactivation in cancer patients receiving chemotherapy. Clin Microbiol Infect. 2008;14(3):221-7.

30. Söderberg-Nauclér C, Rahbar A, Stragliotto G. Survival in patients with glioblastoma receiving Valganciclovir. N Engl J Med. 2013;369(10):985-6.

\section{Publisher's Note}

Springer Nature remains neutral with regard to jurisdictional claims in published maps and institutional affiliations.

Ready to submit your research? Choose BMC and benefit from:

- fast, convenient online submission

- thorough peer review by experienced researchers in your field

- rapid publication on acceptance

- support for research data, including large and complex data types

- gold Open Access which fosters wider collaboration and increased citations

- maximum visibility for your research: over $100 \mathrm{M}$ website views per year

At BMC, research is always in progress.

Learn more biomedcentral.com/submissions 